\title{
Oropharyngeal (p16-Negative) Cancer TNM Finding v8
}

National Cancer Institute

\section{Source}

National Cancer Institute. Oropharyngeal (p16-Negative) Cancer TNM Finding v8. NCI

Thesaurus. Code C132909.

A finding about one or more characteristics of p16-negative oropharyngeal cancer, following the rules of the TNM AJCC v8 classification system. This staging system applies to p16-negative squamous cell carcinomas of the oropharynx, oropharyngeal cancers without p16 immunostaining performed, minor salivary gland carcinomas of the oropharynx, and neuroendocrine carcinomas of the oropharynx. Oropharyngeal cancers which are p16-positive are staged according to the classification for p16-positive oropharyngeal cancers. (from AJCC 8th Ed.) 